\title{
Inocybe vroglindeana, a nevv species of the genus Inocybe, thriving in exposed habitats with calcareous sandy soil
}

\section{Ditte Bandini*, Jukka Vauras ${ }^{2}$, Øyvind Weholt ${ }^{3}$, Bernd Oertel ${ }^{4}$ and Ursula Eberhardt ${ }^{5}$}

1 Panoramastr. 47, 69257 Wiesenbach, Germany

2 Biological Collections of Åbo Akademi University,

Herbarium, University of Turku,

FI-20014 Turku, Finland

3 Høyåslia 9, N-1657 Torp, Norway

4 Höhenweg 15, 53347 Alfter, Germany

5 Staatliches Museum für Naturkunde Stuttgart,

Rosenstein 1, 70191 Stuttgart, Germany

*Corresponding author:

ditte.bandini@gmx.de

Key words: Agaricales, Inocybaceae, Inocybe,

Taxonomy, Type studies, Europe, Molecular systematics, ITS, LSU

\section{Article info:}

Received: 01 March 2020

Accepted: 13 June 2020

Published online: 25 August 2020

Corresponding Editor: Riikka Linnakoski
We describe a smooth-spored species of Inocybe, the basidiomes of which have been encountered growing with Salix in exposed habitats, often with calcareous sandy soils in Germany and Fennoscandia. The species is presented with a detailed description, photographs and microdrawings. Its relationship to similar taxa growing in the same environments is illustrated with ITS and LSU data. Morphologically the species would be keyed out as a member of I. sect. Tardae. For comparison, the types of somewhat similar species occurring in similar habitats as I. woglindeana, i.e. I. subpelargonium, I. rufuloides, I. inodora, I. neorufula and I. variispora, were examined morphologically; from the latter ITS and $\mathrm{mtSSU}$ V6 data were obtained. Molecular data supported a very close relationship between I. woglindeana and I. variispora. The two species are also morphologically similar, but differ in colour of pileus, in shape and details of hymenial cystidia, and also in their host and habitat. None of the other species, represented by our own collections or sequences from the public domain, are phylogenetically closely related to I. woglindeana. 


\section{Introduction}

Until recently the genus Inocybe has been divided into three subgenera - Mallocybe, Inosperma and Inocybe - (Kuyper 1986, Stangl 1989, Bon 1997, 1998), or according to Matheny and Kudzma (2019) into five major clades, Inocybe, Pseudosperma, Inosperma, Mallocybe and Nothocybe. In a recent study, Matheny et al. (2019) raised those clades to the rank of genera, thus, the genus Inocybe is reduced to what used to be $I$. subgenus Inocybe, characterised by e.g. mostly thick-walled hymenial cystidia. This character is not shared by the newly created genera for the other former subgenera or clades of the former circumscription of Inocybe.

Species of the genus Inocybe may be smooth- or nodulose-spored or show a mixture of both, for instance in I. diabolica Vauras, I. ambigua Romagn., or the recently described I. pluppiana Bandini, B. Oertel \& U. Eberh. (Bandini et al. 2020). An important criterium in keys for the identification of species of Inocybe is the question whether the metuloid caulocystidia descend down to the base of the stipe, or whether they are restricted to the apex, or the upper third/fourth of the stipe, and the species are classified respectively in different sections and subsections. According to the classification system used by Marcel Bon in his keys (Bon 1997, 1998), the species described here would have to be assigned to $I$. sect. Tardae, defined by Bon as comprising smoothspored species, the stipes of which are pruinose down to a fourth or third of the stipe.

Whereas in our experience most species of Inocybe preferably grow along shady path- or roadsides, in parks, in cemeteries etc., the basidiomes of $I$. woglindeana have been found in more extreme habitats that are sun-exposed locations with calcareous soil, as for instance at old limestone quarries and limestone processing plants (see below). Based on the currently known material, it is always associated with Salix, often with Salix caprea, and also often with Populus. As such locations are comparatively rare in temperate and boreal Europe, I. woglindeana probably has been overlooked, despite its striking combination of characters or it has been mistaken for other species growing in the same habitat or for I. queletii Konrad.

\section{Materials and methods}

Fresh material was obtained on a number of forays in Finland, Germany and Norway between 1991 and 2017. Type material was loaned from various herbaria. For fresh collections, the relevant macroscopic details, i.e. habit, size and shape of the basidiomes, colour and surface of the pileus, number, colour and edge-type of lamellae, size, colour, surface and base of the stipe, smell and colour of flesh, colour of exsiccata, habitat and surrounding trees, were noted.

For all collections - if possible in the fresh, otherwise in the dried state - basidia, spores, hymenial cystidia, caulocystidia etc. were examined in water and $3 \% \mathrm{KOH}$ solution, with a Leica DM-750 microscope in water and $3 \% \mathrm{KOH}$ solution, at 400 and 1000 magnifications (German collections of D. Bandini), and with a Leitz Laborlux D microscope in $10 \% \mathrm{NH}_{4} \mathrm{OH}$ solution, at 500 and 1250 magnification (Finnish collections of J. Vauras). Photographs of microdetails have been taken with a Zeiss AxioCam ERc5s. The measurements of spores and cystidia were determined using Zeiss Axiovision version 4.8. Cystidia were measured without crystals and basidia without sterigmata. The size of all elements measured is given as length $\times$ width. The $Q$ value means the ratio of spore length to spore width (calculated for each spore). The number of spores or cystidia measured is included in the description.

The pictures of fresh collections on Figure 3 were taken by D. Bandini with a Panasonic Lumix GH2 with a Leica DG Macro-Elmarit 1:2.8/45 mm lens. For the determination of the colour temperature, a calibration card was photographed together with the fresh collections at the collection site. The RAW files were developed with Silkypix Developer Studio 4.0. The photographs of fresh collections in Figures 4-5 were taken by J. Vauras with a Olympus OM-1 N with O=M Zuiko Macro 1:3.5 $50 \mathrm{~mm}$ lens, using Fuji Velvia RVP film, and scanning the slides with a Nikon Coolscan V ED.

Colour codes are taken from Munsell (2009, as "Mu") for the German collections, and from Küppers (1981, as “Kü”) and Cailleux (1981, as “Ca”) for the Finnish collections. Terminology follows Vellinga (1988) and Kuyper (1986). Herbarium acronyms are according to Holmgren et al. (1990), the acronym 
DB refers to the private herbarium of Ditte Bandini.

DNA was extracted from dried material following the protocol described by Cripps et al. (2019). PCR amplification of the ITS follows Cripps et al. (2019), for recent collections the same PCR conditions were used to amplify larger fragments of ITS and nrLSU with standard primers (ITS1F, ITS4, LR0R, LR5; Vilgalys \& Hester 1990, White et al. 1990, LoBuglio et al. 1991, Gardes \& Bruns 1993). The same PCR conditions were also applied to amplify the variable region 6 (V6) of the mtSSU of selected collections. Primers were v6u and v6r (Gonzalez \& Labarère 1998). Bidirectional Sanger sequencing was carried out at LGC (Berlin, Germany). Sequences were assembled and edited using Sequencher vs. 4.8 (Genecodes). Newly generated sequences were submitted to GenBank with acc. no. MN319696 and MT101872-MT101896. Raw data for sequences MT101888-MT101896 were generated by Alvalab.

Collections and sequences included in the analyses were selected to represent I. woglindeana, its closest relatives in terms of sequence similarity, recovered through BLAST searches against GenBank and UNITE (Altschul et al. 1990; downloaded Dec. 2019), and species discussed as morphologically similar. To allow for easier comparison with other published work, we added some sequences from public collections assigned to species discussed here, although we have not seen the material. Following Matheny et al. (2019) sequences of I. relicina (Fr.) Quél. (the type species of the genus Inocybe), Nothocybe distincta (K.P.D. Latha \& Manim.) Matheny \& K.P.D. Latha and as outgroup Pseudosperma spurium (Jacobsson \& E. Larss.) Matheny \& Esteve-Rav. were added. Metadata of sequences used in the analysis are summarized in Table 1.

Alignments were viewed and reformatted using AliView 1.26 (Larsson 2014). Sequences were aligned using the online version of Mafft with the E-INS-i option (Katoh et al. 2005, 2019). The final alignment encompasses 46 collections and 1797 positions (ITS \& nrLSU) plus 201 positions mtSSU. For all collections, the complete ITS fragment was available, apart from I. variispora for which only $5.8 \mathrm{~S}$ \& ITS2 could be amplified and a downloaded sequence, originally identified as I. queletii (EU307813) includes only LSU. Twenty-two sequences in the alignment included nrLSU (see Table 1) and five
mtSSU data (I. variispora and four collections of $I$. woglindeana).

Distance values were calculated as p-distances in PAUP* vs. 4.0a build 167 (Swofford 2002) considering only the ITS between the primers ITS1 and ITS4 or 58SF and ITS4. Maximum Likelihood analyses were done in RAxML vs. 8.2 (Stamatakis 2014) locally or on CIPRES (Miller et al. 2010) with the GTRGAMMA option, 10 searches for the best ML tree with 1000 replicates. The tree was drawn in FigTree 1.4.2 (Rambaut 2006-2018).

\section{Results}

Figure 1 shows the result of the ML analysis. Apart from collections studied morphologically and assigned to Inocybe woglindeana, some of these originally identified as I. queletii, the I. woglindeana clade includes the type of $I$. variispora and sequences from basidiome, soil or ectomycorrhiza samples from Sweden, Estonia and Alaska. Its sister branches, presumably representing two putative species, consist of sequences for which no names could be found. These include, apart from environmental samples, a collection of ours (DB25-5-13-5) and a collection from Thailand (DED8054a).

Species that could be confused with I. woglindeana, including I. queletii, are all very distinct from $I$. woglindeana. What we consider a representative of I. queletii, occurs as sister to I. exilis. Sequences of specimens that were selected to represent species for which no type sequence exists, occur in the same clades as their conspecifics (if they have any). Thus, the species delimitation is in most taxa clear in the tree, but there are exceptions (I. pruinosa and I. inodora, I. involuta and I. nitidiuscula). The placement of downloaded sequences is in all cases within the same clade as conspecifics selected by us, whether or not all of the alleged conspecifics are indeed conspecific is a different question and not part of this study.

The I. woglindeana clade is not supported by bootstrap, although distance values show that the similarity within the clade $(98.2-100 \%)$ is much larger than to the clade of Inocybe sp. DB25-5-13-5 (92.9-94.5) and to Inocybe sp. DED8054a from Thai- 
Table 1. Sequences included in the analyses. Accessions include the ITS and LSU, unless indicated otherwise. * - ITS only, ${ }^{* *}$ - ITS2 only, ${ }^{* * *}$ - LSU only; DB = private herbarium Ditte Bandini, SMG-GME = Collection Sociedad Micologica Gallarta-Gallarta Mikologia Elkarte.

\begin{tabular}{|c|c|c|c|c|c|c|}
\hline SPECIES & VOUCHER NO. & OTHER NUMBERS & HERBARIUM & COUNTRY & $\begin{array}{l}\text { GENBANK/ } \\
\text { UNITE }\end{array}$ & PUBLISHED \\
\hline $\begin{array}{l}\text { Inocybe exilis (Kuyper) } \\
\text { Jacobsson \& E. Larss. }\end{array}$ & DB25-5-13-11 & BAN386 & DB & Germany & MT101888* & here \\
\hline I. exilis & $\begin{array}{l}\text { SMNS- } \\
\text { STU-F-0901441 }\end{array}$ & $\begin{array}{l}\text { DB28-9-15-16, } \\
\text { BAN2857 }\end{array}$ & STU & Austria & MT101873 & here \\
\hline I. exilis & $J V e 06575$ & & & Denmark & FN550919 & $\begin{array}{l}\text { Ryberg et al. } \\
2010\end{array}$ \\
\hline $\begin{array}{l}\text { I. griseotarda Poirier } \\
\text { (holotype) }\end{array}$ & J. Poirier 19901119-01 & & GK & France & MF361839* & Bizio et al. 2017 \\
\hline I. griseotarda & KR-M-0038015 & DB18-9-11-1, BAN148 & $\mathrm{KR}$ & Netherlands & MT101889* & here \\
\hline I. inodora Velen. & $\begin{array}{l}\text { SMNS- } \\
\text { STU-F-0901439 }\end{array}$ & $\begin{array}{l}\text { DB26-9-15-14, } \\
\text { BAN2855 }\end{array}$ & STU & Austria & MT101875 & here \\
\hline I. inodora & EL2405 & & GB & Norway & AM882834.2 & $\begin{array}{l}\text { Ryberg et al. } \\
2008\end{array}$ \\
\hline I. inodora & $\begin{array}{l}\text { SMNS- } \\
\text { STU-F-0901438 }\end{array}$ & $\begin{array}{l}\text { DB24-9-15-11, } \\
\text { BAN2854 }\end{array}$ & STU & Austria & MT101874 & here \\
\hline I. involuta & $\begin{array}{l}\text { SMNS- } \\
\text { STU-F-0901270 }\end{array}$ & $\begin{array}{l}\text { DB13-10-16-19, } \\
\text { BAN2849 }\end{array}$ & STU & Austria & MN512329 & $\begin{array}{l}\text { Bandini et al. } \\
2020\end{array}$ \\
\hline $\begin{array}{l}\text { I. involuta Kuyper } \\
\text { (holotype) }\end{array}$ & L 0017086 & & L & Netherlands & MN319696* & here \\
\hline $\begin{array}{l}\text { I. neorufula Este- } \\
\text { ve-Rav., Macau \& } \\
\text { Ferville (isotype) }\end{array}$ & $\begin{array}{l}\text { SMNS- } \\
\text { STU-F-0901287 }\end{array}$ & AH40223, BAN2357 & STU & Spain & MT101890* & here \\
\hline I. neorufula & $\begin{array}{l}\text { SMNS- } \\
\text { STU-F-0901445 }\end{array}$ & $\begin{array}{l}\text { DB30-10-15-2-Dondl, } \\
\text { BAN2861 }\end{array}$ & STU & Italy & MT101876 & here \\
\hline $\begin{array}{l}\text { I. nitidiuscula (Britzelm.) } \\
\text { Lapl. (epitype) }\end{array}$ & M-0229745 & & M & Germany & KM873364* & $\begin{array}{l}\text { Marchetti et al. } \\
2014\end{array}$ \\
\hline I. nitidiuscula & DB16-8-11-15 & BAN140 & DB & Germany & MT101891* & here \\
\hline I. pruinosa R. Heim & $\begin{array}{l}\text { SMNS- } \\
\text { STU-F-0900987 }\end{array}$ & $\begin{array}{l}\text { DB13-10-12-11, } \\
\text { BAN2336 }\end{array}$ & STU & Germany & MT101877 & here \\
\hline I. pruinosa & EL24106 & & GB & France & FN550904 & $\begin{array}{l}\text { Ryberg et al. } \\
2010\end{array}$ \\
\hline $\begin{array}{l}\text { I. pseudodestricta } \\
\text { Stangl \&J. Veselský } \\
\text { (holotype) }\end{array}$ & PRM716231 & & PRM & $\begin{array}{l}\text { Czech } \\
\text { Republic }\end{array}$ & MG012468 & $\begin{array}{l}\text { Bandini et al. } \\
2019\end{array}$ \\
\hline I. pseudodestricta & KR-M-0043223 & $\begin{array}{l}\text { DB6-5-12-10, } \\
\text { BAN102 }\end{array}$ & $\mathrm{KR}$ & Netherlands & MT101892* & here \\
\hline I. queletii Konrad & KR-M-0038286 & DB22-5-12-1, BAN160 & $\mathrm{KR}$ & Germany & MT101893* & here \\
\hline I. relicina & JV10258, IB19920112 & & WTU, IB & Finland & $\begin{array}{l}\text { AF325664, } \\
\text { AY038324 }\end{array}$ & $\begin{array}{l}\text { Peintner et al. } \\
\text { 2001, Matheny } \\
\text { et al. } 2002\end{array}$ \\
\hline I. rufuloides Bon & $\begin{array}{l}\text { SMNS- } \\
\text { STU-F-0901442 }\end{array}$ & $\begin{array}{l}\text { DB13-10-12-4, } \\
\text { BAN2858 }\end{array}$ & STU & Germany & MT101878* & here \\
\hline I. rufuloides & JVe061110 & & & Italy & FN550921 & $\begin{array}{l}\text { Ryberg et al. } \\
2010\end{array}$ \\
\hline I. rufuloides & PERTH 7700598 & E8353 & PERTH & Australia & $\begin{array}{l}\text { JN035292, } \\
\text { JN035295 }\end{array}$ & \begin{tabular}{|l|} 
Bougher \& \\
Matheny 2011 \\
\end{tabular} \\
\hline I. subporospora Kuyper & RP950618 & & & Sweden & AM882931.2 & $\begin{array}{l}\text { Ryberg et al. } \\
2008\end{array}$ \\
\hline I. subporospora Kuyper & DB2-10-12-2 & BAN266 & DB & Germany & MT101895* & here \\
\hline
\end{tabular}




\begin{tabular}{|c|c|c|c|c|c|c|}
\hline $\begin{array}{l}\text { I. variispora Fern. Sas. } \\
\text { (isotype) }\end{array}$ & 980504-01 & BAN2804 & SMG-GME & Spain & $\begin{array}{l}\text { MT101872**, } \\
\text { MT101883(V6) }\end{array}$ & here \\
\hline $\begin{array}{l}\text { I. woglindeana Bandini, } \\
\text { Vauras \& Weholt } \\
\text { (holotype) }\end{array}$ & $\begin{array}{l}\text { SMNS- } \\
\text { STU-F-0901435 }\end{array}$ & $\begin{array}{l}\text { DB12-5-13-2, } \\
\text { BAN2851 }\end{array}$ & STU & Germany & $\begin{array}{l}\text { MT101882, } \\
\text { MT101887 (V6) }\end{array}$ & here \\
\hline I. woglindeana & DB25-5-13-1 & BAN373 & DB & Germany & MT101896* & here \\
\hline I. woglindeana & \begin{tabular}{|l|} 
SMNS- \\
STU-F-0901448
\end{tabular} & $J V 26781$ & STU & Finland & $\begin{array}{l}\text { MT101880, } \\
\text { MT101885 (V6) }\end{array}$ & here \\
\hline I. woglindeana & \begin{tabular}{|l|} 
SMNS- \\
STU-F-0901449
\end{tabular} & JV29347 & STU & Finland & $\begin{array}{l}\text { MT101881, } \\
\text { MT101886 (V6) }\end{array}$ & here \\
\hline I. woglindeana & $\begin{array}{l}\text { SMNS- } \\
\text { STU-F-0901434 }\end{array}$ & $\begin{array}{l}\text { DB10-10-17-19, } \\
\text { BAN2850 }\end{array}$ & STU & Germany & $\begin{array}{l}\text { MT101879, } \\
\text { MT101884 (V6) }\end{array}$ & here \\
\hline $\begin{array}{l}\text { I. woglindeana (soil } \\
\text { sample }\end{array}$ & & G4776 & & Estonia & UDB0510120* & $\begin{array}{l}\text { Tedersoo et } \\
\text { al. Global soil } \\
\text { samples unpub- } \\
\text { lished }\end{array}$ \\
\hline $\begin{array}{l}\text { I. woglindeana (soil } \\
\text { sample }\end{array}$ & & G4231 & & Estonia & UDB0303831* & $\begin{array}{l}\text { Tedersoo et } \\
\text { al. Global soil } \\
\text { samples unpub- } \\
\text { lished }\end{array}$ \\
\hline $\begin{array}{l}\text { I. woglindeana (soil } \\
\text { sample }\end{array}$ & & G3562 & & Estonia & UDB0347354* & $\begin{array}{l}\text { Tedersoo et } \\
\text { al. Global soil } \\
\text { samples unpub- } \\
\text { lished }\end{array}$ \\
\hline $\begin{array}{l}\text { I. woglindeana (soil } \\
\text { sample }\end{array}$ & & G3564 & & Estonia & UDB0356290* & $\begin{array}{l}\text { Tedersoo et } \\
\text { al. Global soil } \\
\text { samples unpub- } \\
\text { lished }\end{array}$ \\
\hline $\begin{array}{l}\text { I. woglindeana as } \\
\text { I. queletii }\end{array}$ & TUR 147244 & $\begin{array}{l}\text { JV13784F, FI- } \\
\text { PUT476-14 }\end{array}$ & TUR-A & Finland & UDB022396* & $\begin{array}{l}\text { Bálint Dima, } \\
\text { unpublished }\end{array}$ \\
\hline $\begin{array}{l}\text { I. woglindeana as } \\
\text { I. queletii }\end{array}$ & JV19682F & & CUW & Finland & EU307813*** & $\begin{array}{l}\text { Kropp et al. } \\
2010\end{array}$ \\
\hline $\begin{array}{l}\text { I. woglindeana as } \\
\text { Inocybe sp. }\end{array}$ & EL404 & & GB & Sweden & AM882968 & $\begin{array}{l}\text { Ryberg et al. } \\
2008\end{array}$ \\
\hline $\begin{array}{l}\text { I. woglindeana as } \\
\text { Inocybe sp. }\end{array}$ & TUR 182154 & $\begin{array}{l}\text { JV5898F, FI- } \\
\text { PUT578-14 }\end{array}$ & TUR-A & Finland & UDB022408* & $\begin{array}{l}\text { Bálint Dima, } \\
\text { unpublished }\end{array}$ \\
\hline Inocybe sp. & DB25-5-13-5 & BAN384 & DB & Germany & MT101894* & here \\
\hline Inocybe sp. & DED8054a & & SFSU & Thailand & $\begin{array}{l}\text { GQ892998, } \\
\text { GQ892953 }\end{array}$ & $\begin{array}{l}\text { Horak et al. } \\
(2015)\end{array}$ \\
\hline $\begin{array}{l}\text { Inocybe sp. } \\
\text { (ectomycorrhiza) }\end{array}$ & & $\begin{array}{l}\text { morphotype } 12 \text {, isolate } \\
140\end{array}$ & & Austria & EU326161* & $\begin{array}{l}\text { Mühlmann \& } \\
\text { Peintner } 2008\end{array}$ \\
\hline $\begin{array}{l}\text { Inocybe sp. } \\
\text { (soil sample) }\end{array}$ & & $\begin{array}{l}\text { clone 87_NA11_P31_ } \\
\text { E1/ OTU470 }\end{array}$ & & USA, Alaska & KC965603* & $\begin{array}{l}\text { Timling et al. } \\
2014\end{array}$ \\
\hline $\begin{array}{l}\text { Inocybe sp. } \\
\text { (soil sample) }\end{array}$ & & clone IIS4-12 & & Austria & EU517033* & \begin{tabular}{|l} 
Oberkofler \& \\
Peintner 2008
\end{tabular} \\
\hline Nothocybe distincta & ZT 9250, CAL 1310 & & $\mathrm{ZT}, \mathrm{CAL}$ & India & $\begin{array}{l}\text { KX171343, } \\
\text { EU604546 }\end{array}$ & $\begin{array}{l}\text { Latha et al. 2016, } \\
\text { Matheny et al. } \\
2009\end{array}$ \\
\hline $\begin{array}{l}\text { Pseudosperma spurium } \\
\text { (holotype) }\end{array}$ & SJ92-017 & & GB & Sweden & AM882784.2 & $\begin{array}{l}\text { Ryberg et al. } \\
2008\end{array}$ \\
\hline Pseudosperma spurium & BK180809723 & & UTC & USA, Utah & $\begin{array}{l}\text { JQ408794, } \\
\text { EU600868 }\end{array}$ & $\begin{array}{l}\text { Kropp et al. } \\
\text { 2013, Matheny } \\
\text { et al. } 2009\end{array}$ \\
\hline
\end{tabular}




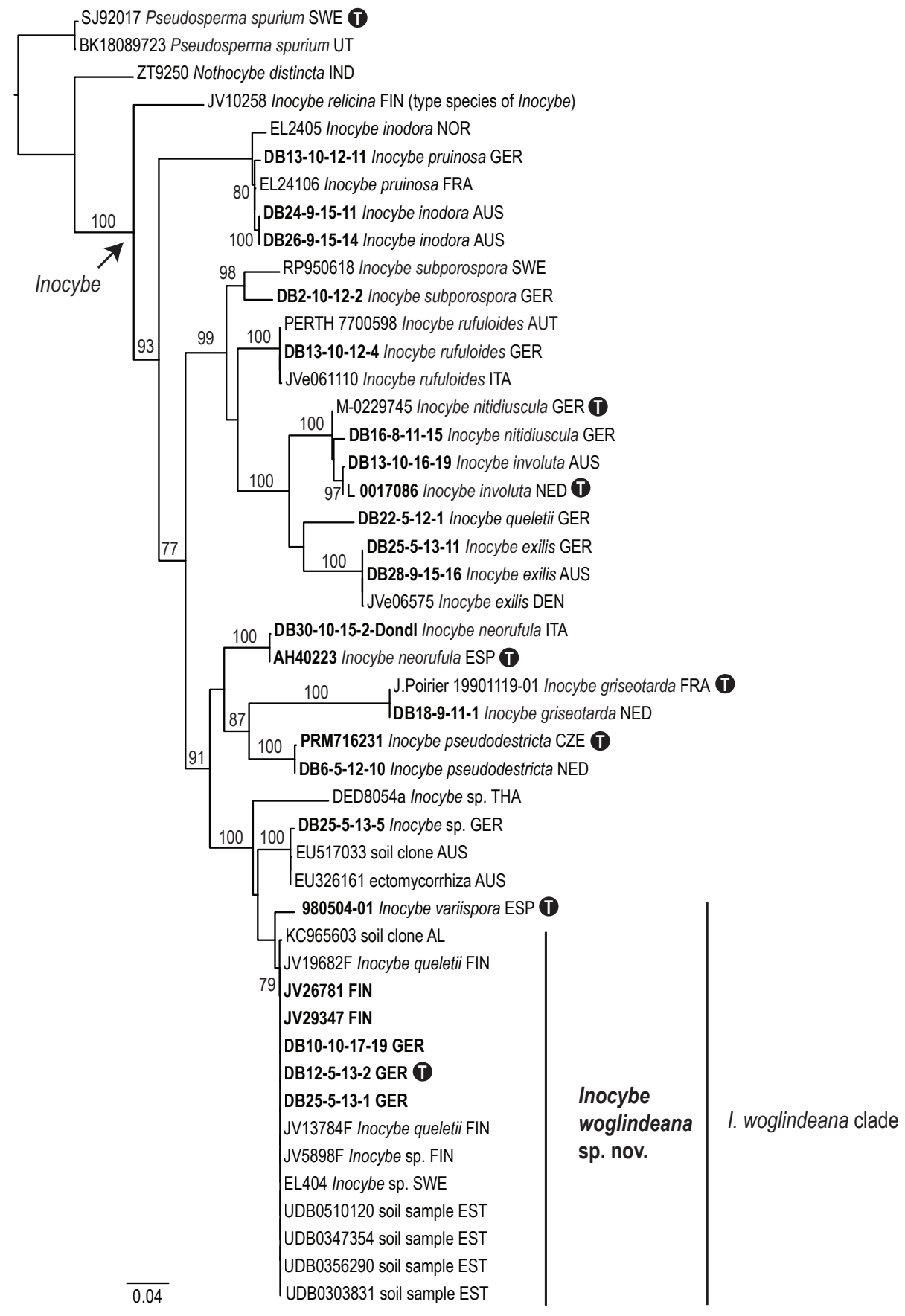

Fig. 1. ML topology calculated under the GTRGAMMA model. Branch support from 1000 replicates of bootstrap. Collection numbers in bold refer to material studied by us. T - type. AL - Alaska, AUS - Austria, AUT - Australia, CZE - Czech Republic, DEN - Denmark, ESP - Spain, EST - Estonia, FIN - Finland, FRA - France, GER Germany, IND - India, ITA - Italy, NED - Netherlands, NOR - Norway, SWE - Sweden, UT - Utah. 
land (87.8-93.4\%). The sequence similarity between the ITS sequences of studied collections of I. woglindeana is $100 \%$, including also sequence data from Estonia, from collection EL404 (Sweden) and environmental sequences $99.7-100 \%$.

The split between I. variispora and the other members of the I. woglindeana clade is only weakly supported (Fig. 1). For the comparisons with I. variispora only the ITS2 fragment is available (430 positions). All studied collections of I. woglindeana, collection EL404 and all European soil or root derived sequences are identical in terms of p-values. These sequences are $98.3-98.5 \%$ similar to $I$. variispora, with missing data being responsible for the lower values. The Alaskan soil clone (without missing data) is $98.2 \%$ similar to I. variispora, and $99.7 \%$ to the former group. The I. variispora ITS2 has an insertion of $5 \mathrm{bp}$ compared to the other sequences from the I. woglindeana cluster. The Alaskan sample has an insertion of $2 \mathrm{bp}$ and another one of $4 \mathrm{bp}$ compared to all of the other sequences in the I. woglindeana clade, including I. variispora. For the sequences for which we have the raw data (i.e. data submitted in the context of this study), we know that these insertions are unambiguously absent from I. woglindeana; also, the raw data of I. variispora is unambiguous with a view to these indels. There are 7 substitutions in the V6 variable region of the I. variispora type compared to the four sequences of $I$. woglindeana.

In conclusion, based on the molecular analyses, we consider I. woglindeana as a species distinct from I. variispora. We consider it very likely that the sequences from northern European samples that cluster with the studied collections of I. woglindeana are also members of this species. The same is true, albeit with some reservation, for the Alaskan sequence.

\section{Taxonomy}

Inocybe woglindeana Bandini, Vauras \& Weholt sp. nov.

- Figs. 2-5

MycoBank number: MB834803;

ITS GenBank MT101882
ETYMOLOGY: “woglindeana”, after Woglinde the Rhinemaiden in the "Ring der Nibelungen" of Richard Wagner, because the holotype of the species was collected on the border of a lake next to the river Rhine.

DIAGNOSIS: Most basidiomes fairly small with ochraceous to ochraceous brownish felty-lanose pileus, when young usually with ample whitish velipellis and cortina, a stipe that is sparsely pruinose only at the extreme apex, spores that on average are longer than $10 \mu \mathrm{m}$, hymenial cystidia that are mostly ventricose with rather thin walls and often with a truncate or roundish base. It grows on exposed locations, mostly with Salix and also Populus nearby. The most similar species morphologically as well as molecularly is I. variispora. From this and other species it differs by the above-named combined characteristics and by ITS sequence data.

Holotype - Germany, Rheinland-Pfalz, RheinPfalz-Kreis, Altrip, TK25 6516/4, alt. 95 m, sandy lake shore with Salix sp., Populus sp., Betula pendula, Pinus sylvestris, 12 May 2013, leg. D. Bandini \& B. Oertel (Holotype STU SMNS-STU-F-0901435, BAN2851; Isotypes personal collection D. Bandini DB12-5-132, TUR-A 208610, AH 46945).

DESCRIPTION - PILEUS 15-30 (45) mm wide, at first almost globulose, soon mostly (sub)conical, more rarely (sub)campanulate, later broadly convex or expanded, often without umbo, seldom with more or less pronounced large umbo, margin at first involute, then deflexed, later straight to uplifted, and then pileus slightly depressed around the centre; when young entirely or radially covered with a whitish velipellis, later still visible mostly on or around the centre; colour because of the velipellis dingy beige or pale straw-coloured, straw-coloured, later ochraceous to ochraceous brownish in different nuances (Mu 10YR 7/4-7/8, 6/6-6/8, 5/4-5/6, also 8/48/6, 7.5YR 6/6-6/8, Kü S 10Y40M30, S 10Y30M20, Ca $77 \mathrm{M}, 77 \mathrm{~N})$, at the umbo often somewhat paler due to the velipellis, sometimes with a faint orange hue; surface at first finely felty, then thickly felty or felty-lanose with appressed fibres, when old or due to weather-circumstances, also with lacerate fibrous bundles especially towards the margin; at the centre occasionally areolate-diffracted or subscaly; young 


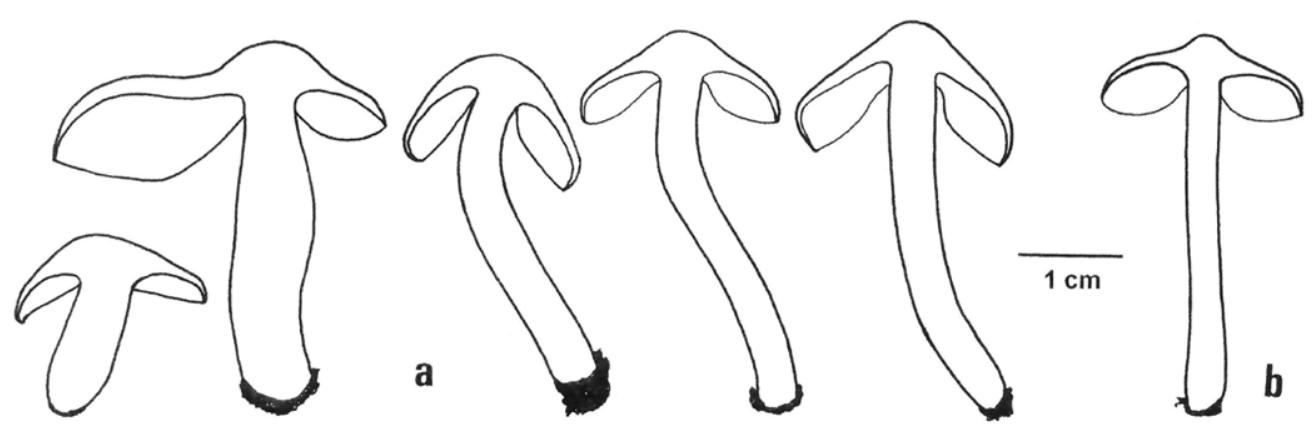

Fig. 2. Inocybe woglindeana. Basidiomes a: coll. Vauras 13558F. b: coll. Vauras 5898F; drawing J. Vauras.

basidiomata with ample whitish cortina. LAMELLAE mostly (sub)distant (ca. 30-45 (50), 1 = 1-3), to $8 \mathrm{~mm}$ broad, adnate or emarginate adnate, or subdecurrent, ventricose, at first and for long time conspicuously whitish, beige or ivory-coloured, near the margin also yellowish, then greyish light brown (Mu 10YR 5/4-5/6, Ca 70M) to grey-brown (Mu 10YR 4/4-4/6, Kü S 30Y50M30, Ca 70N), sometimes with pale pinkish hue, when old also with rusty-brownish blotches; edge fimbriate, whitish. STIPE 20-50 $\times$ 1.5-8 mm, cylindrical or slightly widening towards the base, when young entirely covered with whitish tomentum, later longitudinally white-fibrillose, striate or glabrous, at first whitish, then with faint yellowish or ochraceous tinge or slightly flesh-coloured beneath the tomentum, sometimes faintly yellowish, especially towards the base, when older yellow-brown (Kü S 10Y40M30, Ca 65N); only sparsely pruinose at the extreme apex of the stipe. CONTEXT whitish in the pileus near the centre, watery above the lamellae, in the stipe whitish, pale yellowish, pale brown or partially brownish, in the base of the stipe whitish or yellowish, sometimes stipe with faint pinkish tinge. SMELL weak, acidulous to agreeably fragrant when in good condition, not at all spermatic. COLOUR OF EXSICCATA: pileus pale brown to nutbrown, sometimes with faint reddish hue $\mathrm{Mu}$ 7.5YR 5/4-5/8, 5YR 4/4-4/6, Ca 77M, 75N, 75P), lamellae and stipe concolorous or a little lighter in colour, rarely darkening on drying.

SPORES: German collections $8.0-13.0 \mu \mathrm{m}$ (av. $10.2 \mu \mathrm{m}$, SD $0.7 \mu \mathrm{m}) \times 4.9-7.1 \mu \mathrm{m}($ av. $5.9 \mu \mathrm{m}$, SD $0.4 \mu \mathrm{m}) ; \mathrm{Q}$ $=1.4-2.2$ (av. 1.7, SD 0.1) ( $\mathrm{n}=240$ of 6 coll.); Finnish collections 9.0-14.3 $\mu \mathrm{m}$ (av. $11.3 \mu \mathrm{m}) \times 5.3-7.4 \mu \mathrm{m}$ (av. 6.3 $\mu \mathrm{m}$ ); $\mathrm{Q}=1.5-2.2$ (av. 1.8) ( $\mathrm{n}=160$ of 4 coll.), smooth, mostly oblong (sub)amygdaloid or (sub)ellipsoid or subcylindrical, sometimes with faint suprahilar depression, apex subacute, subobtuse or obtuse, occasionally with indistinct pseudopore. BASIDIA 25-30 (32) × 7-10 $\mu \mathrm{m}$, generally 4-spored. LAMELLA EDGE sterile, composed of cheilocystidia and numerous colourless, (sub)clavate, cylindrical or subglobose, thin-walled paracystidia, sometimes also in intermediate states. PLEUROCYSTIDIA: German collections 35-77 $\mu \mathrm{m}$ (av. $57 \mu \mathrm{m}$, SD $11 \mu \mathrm{m}) \times$ 12-31 $\mathrm{m}$ (av. $19 \mu \mathrm{m}, \mathrm{SD} 4 \mu \mathrm{m}$ ); $\mathrm{Q}=1.3-4.9$ (av. 3.3, SD 0.6) ( $\mathrm{n}=90$ of 6 coll.); Finnish collections 51-82 $\mu \mathrm{m}($ av. $67 \mu \mathrm{m}) \times 15-30 \mu \mathrm{m}($ av. $20 \mu \mathrm{m}) ; \mathrm{Q}=2.1-4.9$ (av. 3.3) ( $n=90$ of 6 coll.), rather ventricose subfusiform, (sub)utriform, often characteristically elongate (sub)ellipsoid, somewhat sac-shaped or subcylindrical, usually without or with only a short neck and wide or rounded apex, mostly without pedicel and often with rounded or truncate base, apex mostly crystalliferous, walls usually only up to $1.0 \mu \mathrm{m}$ (neck) thick at the apex, pale yellow in $3 \% \mathrm{KOH}$. CHEILOCYSTIDIA similar in size, but more variable in shape. PILEIPELLIS constituted by an epicutis 

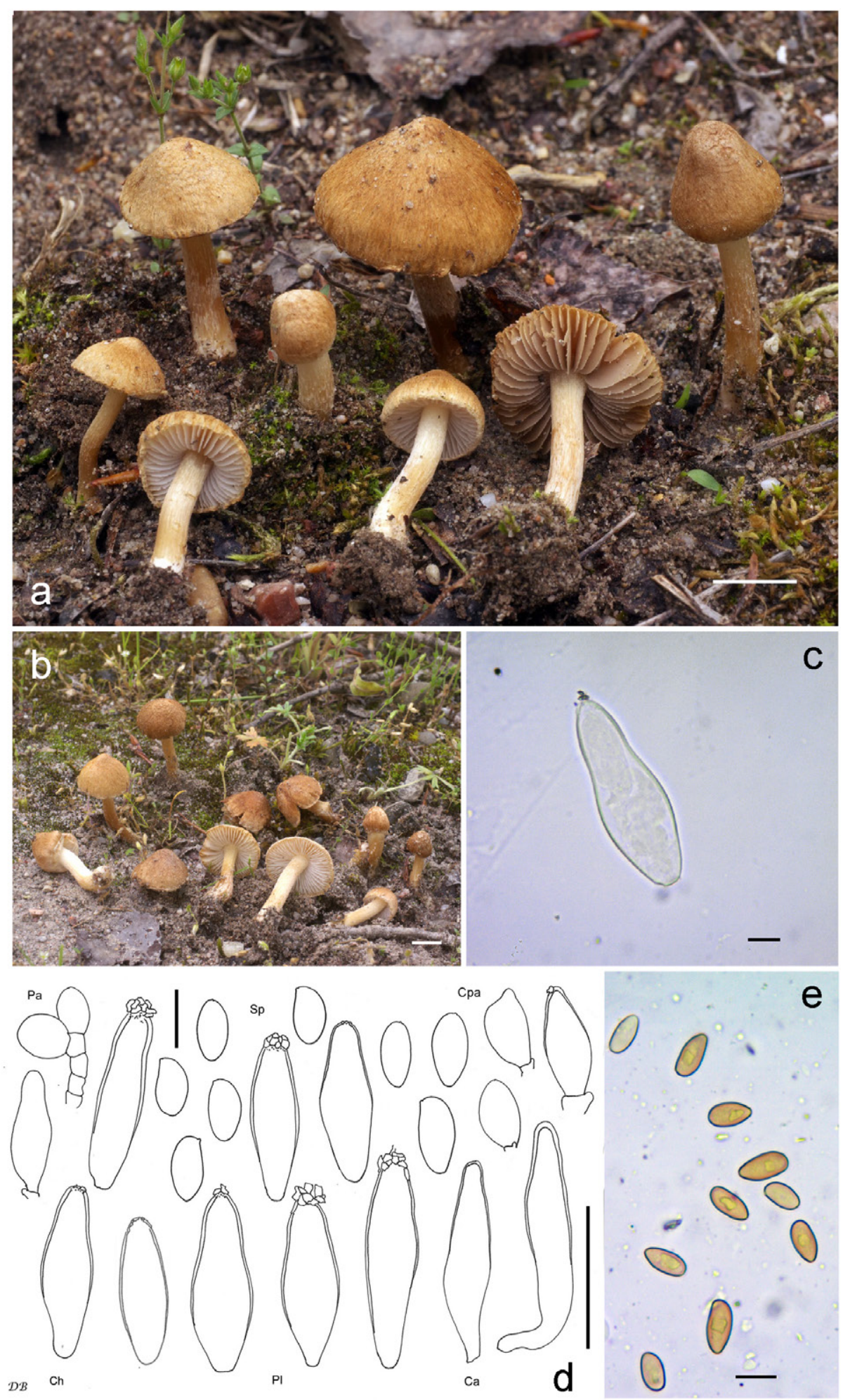

Fig. 3.

Inocybe woglindeana a: coll. DB12-5-13-2, Holotype, scale bar: $1 \mathrm{~cm}$. b: coll. DB25-513-1, scale bar: $1 \mathrm{~cm}$. c: Cheilocystidia (coll. DB25-5-13-1), scale bar: $10 \mu \mathrm{m}$. d: Microscopic characters (coll. DB12-5-13-2), Ca = Caulocystidia, Cpa = Cauloparacystidia, Ch = Cheilocystidia, $\mathrm{Pa}=$ Paracystidia, $\mathrm{PI}$ = Pleurocystidia, Sp = Spores; scale bar spores: $10 \mu \mathrm{m}$, scale bar cystidia: $50 \mu \mathrm{m}$. e: Spores (coll. DB25-5-13-1), scale bar: $10 \mu \mathrm{m}$; photographs and drawing $D$. Bandini. 


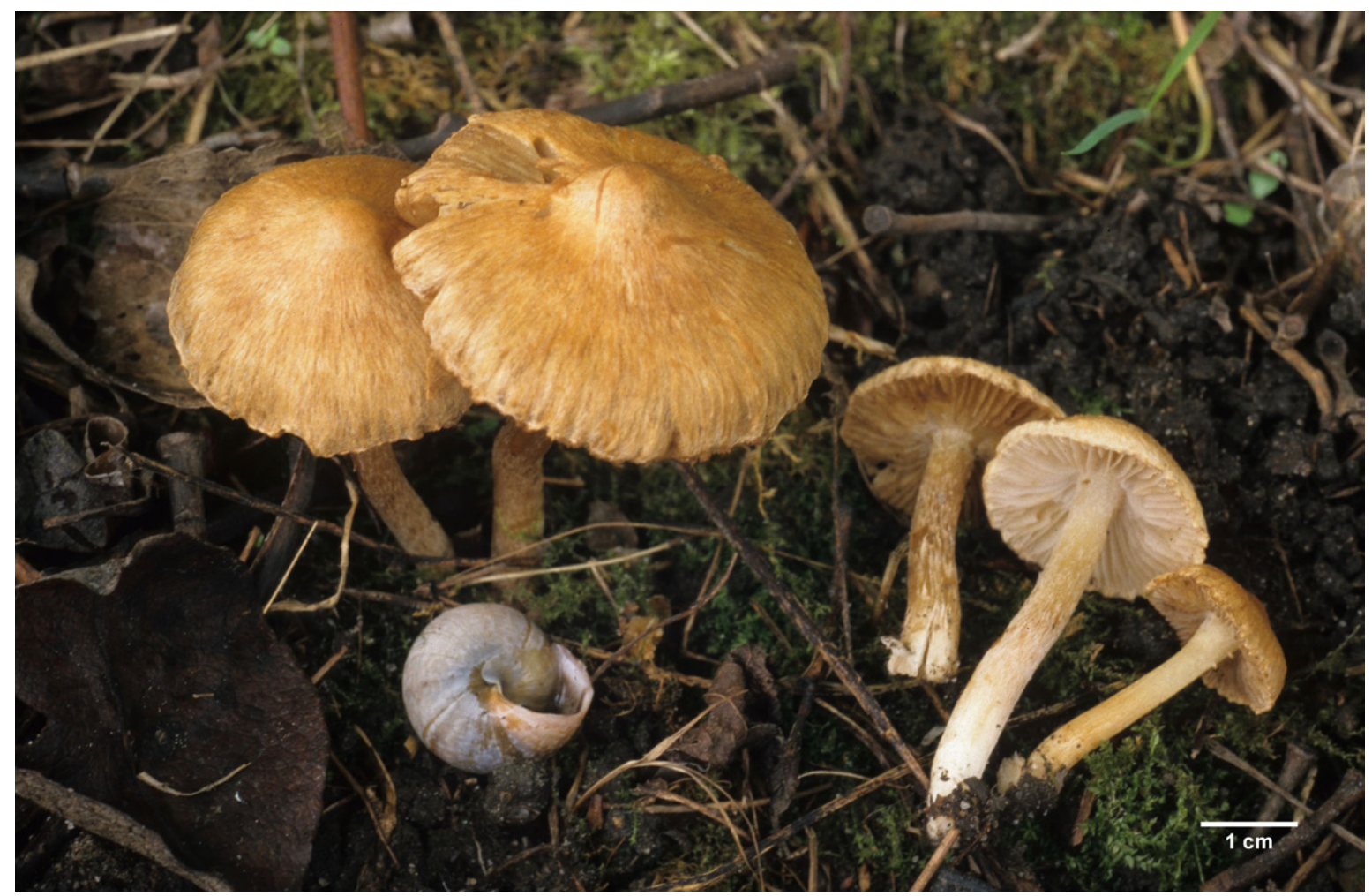

Fig. 4. Inocybe woglindeana, coll. Vauras 13616F; photograph J. Vauras.

made up of parallel hyphae 6-12 $\mu$ m wide, with finely encrusting and parietal ochraceous pigment; subcutis with wider and paler but often also pigmented to hyaline elements, up to $25 \mu \mathrm{m}$; epicutis in young basidiomata often covered with thin (sub)hyphae, with scattered free ends (belonging to velipellis remnants). STIPITIPELLIS consisting of a cutis bearing numerous bundles of rather thin-walled caulocystidia at the extreme apex of the stipe, intermixed with thin-walled colourless cauloparacystidia. CAULOCYSTIDIA 35-75 × 10-20 (25) $\mu \mathrm{m}$, quite variable in shape, (sub)fusiform, (sub)utriform, (sub)cylindrical, (sub)clavate or deformed, apex usually not crystalliferous and rather thin-walled, walls usually only up to $1.0 \mu \mathrm{m}$ thick at the apex, pale yellow in $3 \%$ KOH. CLAMP-CONNECTIONS abundant in all tissues; REFRACTIVE HYPHAE occasionally present in trama of stipe, lamellae and pileus.
ECOLOGY AND ASSOCIATED FUNGIFLORA - All German collections of Inocybe woglindeana were found on exposed dry gravellous and/or sandy poor soil - some collections near the shore of a river or a lake, two on a renaturated railway-terrain and some others next to a calcareous inland-dune-terrain, in a renaturated sand-and gravel-quarry. All locations are sunny and open, thus especially in summer they are quite hot and for long periods near the surface very dry, but nevertheless all with Salix, mostly Salix caprea nearby. Also Betula and/or Populus were noted next to several collections. Pinus sylvestris was noted with several collections as well.

In Finland, I. woglindeana is known from four localities from Southern to Central Finland. These all are human influenced areas with limestone processing plants, limestone quarry or brick-works. 
Further, all are fairly open, in every place with Salix, mostly Salix caprea, and often with other deciduous trees, mostly Populus tremula and Betula pendula. The soil of these localities is sandy and calcareous. The terrain is generally open or somewhat open to direct sun and is quickly warmed and dried - in spite of the presence of Salix. The species I. exilis (Kuyper) Jacobsson \& E. Larss. grows nearby in Germany as well as in Finland, where other accompanying species were e.g. I. vulpinella Bruylants and Mallocybe latispora (Bon) Matheny \& Esteve-Rav.

Also in Norway, I. woglindeana was found associated with deciduous trees including Salix sp. The locality is influenced by past industrial activities (paper industry), and the area also is habitat for a rich flora of Morchella-species. Inocybe woglindeana was found in an area of about $1000 \mathrm{~m}^{2}$. It seems to reappear there annually like Mallocybe dulcamara, which is common in this area.

PHENOLOGY: Inocybe woglindeana is apparently not restricted to a certain season, as it has been found in spring (May), summer (June - August) as well as in autumn (September - October). However, it is one of the earliest species of Inocybe.

Collections studied (Sequenced specimens indicated with asterisk) - FINLAND. Varsinais-Suomi. Lohja, Virkkala, near old limestone plant, margin of meadow, near Salix caprea and Populus tremula, 22 Jun. 1998, leg. J. Vauras 13556 (TUR-A), 13558F (TUR-A), 1 Jul. 1998, leg. J. Vauras 13616F (TUR-A, H), 16 Jul. 1998, leg. J. Vauras 13704 (TUR-A), 13705F (TUR-A, DB), 31 Jul. 1998, leg. J. Vauras 13784F* (TUR-A), 25 Aug. 1998, leg. J. Vauras 14123 (TUR-A), 1 Jul. 2003, leg. J. Vauras 19682F* (TUR-A, GB, WTU).At margin of road in herb-rich forest with Populus tremula, Betula pendula, Salix caprea and Pinus sylvestris, 1 Jul. 2003, leg. J. Vauras 19665 (TUR-A).- Near Evästorppa, margin of sandy yard, near Betula pendula, Salix sp. and Populus tremula, 20 Sep. 2012, leg. J. Vauras 29347* (TUR-A, STU SMNS-STU-F-0901449, DB), 23 Sep. 2013, leg. J. Vauras 30246 (TUR-A).Parainen, Storgård, Malmnäs, near limestone processing plant, 17 Jun. 2009, leg. J. Vauras 26781* (TUR-A, STU SMNS-STU-F-0901448, DB).- Uusimaa. Hanko, Tvärminneby, at abandoned brick-works, old yard with Salix caprea, Populus tremula and Betula pendula, 30 Jun. 1998, leg. J. Vauras 13603 (TUR-A, H, DB).- Keski-Pohjanmaa.- Vimpeli, Koskela, abandoned limestone quarry and limestone plant, near Betula sp., Salix sp., Pinus sylvestris and Alnus incana, 26 Aug. 1991, leg. J. Vauras 5898F* (TUR-A).

GERMANY. Baden-Württemberg, Heidelberg, Südstadt, TK25 6618/1, alt. $110 \mathrm{~m}$, former railway terrain, sandy ground with Salix caprea, Betula pendula, 30 May 2016, leg. D. Bandini (DB30-5-16$\left.1^{*}\right)$.- Ibidem, 5 Jun. 2016, leg. D. Bandini (DB5-6-161).- Rheinland-Pfalz, Rhein-Pfalz-Kreis, Neuhofen, wayside near Kistnerweiher, TK25 6516/4, alt. 95 m, in some distance to type-collection, alt. $90 \mathrm{~m}$, sandy terrain with Populus sp., Salix sp., 12 May 2013, leg.D. Bandini \& B. Oertel (DB12-5-13-6).- Rheinland-Pfalz, Rhein-Pfalz-Kreis, Ludwigshafen am Rhein, TK25 6516/4, alt. 93 m, sandy shore with Populus sp., Salix sp., 25 May 2013, leg. D. Bandini \& B. Oertel (DB255-13-1*).- Rheinland-Pfalz, Rhein-Pfalz-Kreis, Neuhofen, wayside near Kistnerweiher, TK25 6516/4, alt. 95 m, Salix sp., Populus sp., Pinus sylvestris, Betula pendula, 25 May 2013, leg. D. Bandini \& B. Oertel (DB25-5-13-3).- Bayern, Kelheim, Abensberg-Offenstetten, TK25 7137/3, alt. 380 m, Pinus sylvestris, Salix sp., 10 Oct. 2017, leg. D. Bandini (DB10-10-17$\left.18^{*}\right)$.- Ibidem, in some distance to former location, Salix sp., Pinus sylvestris, 10 Oct. 2017, leg. D. Bandini (DB10-10-17-19, STU SMNS-STU-F-0901434*).- Ibidem, in some distance to former location, Salix sp., Pinus sylvestris, 10 Oct. 2017, leg. D. Bandini (DB1010-17-20).- Ibidem, in some distance to former location, Pinus sylvestris, Salix sp., 10 Oct. 2017, leg. $D$. Bandini (DB10-10-17-21).- Ibidem, in some distance to former location, Salix caprea, Pinus sylvestris, Populus tremula, 11 Oct. 2017, leg. D. Bandini \& B. Oertel (DB11-10-17-15*).- Ibidem, in some distance to former location, Salix caprea, Pinus sylvestris, Populus tremula, 12 Oct. 2017, leg. D. Bandini, B. Oertel \& J. Christan (DB12-10-17-17*).

NORWAY. Østfold. Fredrikstad, Torp Bruk, with various deciduous trees, among them Salix sp., Alnus sp., 29 Jun. 1985, leg. Ø. Weholt. First record of the species, originally identified as I. queletii by Th.W. Kuyper and cited in Kuyper (1986, probably deposited in L).- Ibidem, 2 Sep. 2014, leg. M. Pettersen.- Ibidem, 2 Aug. 2015, leg. M. Pettersen (O).- Ibidem, 25 
May 2017, leg. M. Pettersen (O).- Ibidem, 24 May 2019, leg. M. Pettersen.- Ibidem, 5 Jun. 2019, leg. Ø. Weholt (now lost).

ADDITIONAL TYPES STUDIED: HOLOTYPE: INOCYBE INODORA Velen. 1920, Czech Republic, Bilichov, frondose trees, leg. Viniklář, Jun. 1920 (PR, bottle no 156). SPORES 9.0-12.8 $\mu \mathrm{m}$ (av. $11.0 \mu \mathrm{m}$, SD $0.9 \mu \mathrm{m}) \times 5.2-7.4 \mu \mathrm{m}$ (av. $6.2 \mu \mathrm{m}$, SD $0.5 \mu \mathrm{m}$ ); $\mathrm{Q}=1.4-2.1$ (av. 1.8, SD 0.1) $(\mathrm{n}=40)$, smooth, with subacute to (sub)obtuse apex, some with indistinct pseudopore. BASIDIA 4-spored. PLEUROCYSTIDIA 44-68 $\mu \mathrm{m}$ (av. $59 \mu \mathrm{m}$, SD $6 \mu \mathrm{m}) \times 12-25 \mu \mathrm{m}$ (av. 18 $\mu \mathrm{m}$, SD $3 \mu \mathrm{m}) ; \mathrm{Q}=2.6-5.2($ av. 3.4, SD 0.6) $(\mathrm{n}=15)$, mostly (sub)fusiform or subutriform, with short neck and short pedicel, apex usually crystalliferous, walls up to $3.0(3.5) \mu \mathrm{m}$ thick, yellowish-greenish with $3 \%$ KOH. CHEILOCYSTIDIA similar in appearance and size. PARACYSTIDIA (sub)clavate to subovoid. CAULOCYSTIDIA not studied (to preserve the material).

HOLOTYPE: Inocybe involuta Kuyper, Netherlands, Terschelling, 6 Oct. 1988, under Pinus nigra in dune sand, leg. E. Arnolds (L-0017086). SPORES 9.0-13.0 $\mu \mathrm{m}$ (av. 10.5 $\mu \mathrm{m}$, SD $1.0 \mu \mathrm{m}) \times 5.3-7.2 \mu \mathrm{m}$ (av. $6.2 \mu \mathrm{m}$, SD $0.4 \mu \mathrm{m}) ; \mathrm{Q}=1.5-2.0$ (av. 1.7, SD 0.1) $(\mathrm{n}=40)$, smooth, (sub)amygdaloid, with (sub)acute apex, with indistinct pseudopore. BASIDIA 4-spored. PLEUROCYSTIDIA 50-77 $\mu \mathrm{m}$ (av. $64 \mu \mathrm{m}$, SD $7 \mu \mathrm{m}) \times 19-30 \mu \mathrm{m}$ (av. $24 \mu \mathrm{m}$, SD $4 \mu \mathrm{m}$ ); Q = 2.0-4.2 (av. 2.8, SD 0.6) $(\mathrm{n}=15)$, mostly (sub)fusiform or subutriform, apex usually crystalliferous, walls up to 3.0 (3.5) $\mu$ m thick, pale yellowish with $3 \% \mathrm{KOH}$. CHEILOCYSTIDIA similar in appearance and size. PARACYSTIDIA not observed. CAULOCYSTIDIA only in the upper third of the stipe, similar to hymenial cystidia, but somewhat thinner-walled.

ISOTYPE: Inocybe neorufula Esteve-Rav., Macau \& Ferville 2012, Spain, Catalonia, Girona, Torroella de Montgrí, Fraxinus angustifolia, Pinus pin$e a$, leg. J. Carbó \& N. Macau, 6 Dec. 2010 (SMNSSTU-F-0901287). SPORES 9.3-14.3 $\mu \mathrm{m}$ (av. $10.9 \mu \mathrm{m}$, SD $1.0 \mu \mathrm{m}) \times 4.9-6.7 \mu \mathrm{m}($ av. $5.9 \mu \mathrm{m}, \mathrm{SD} 0.4 \mu \mathrm{m}) ; \mathrm{Q}=$ 1.6-2.3 (av. 1.9, SD 0.2) ( $=40)$, smooth, (sub)amgydaloid, with suprahilar depression and (sub)acute to papillate apex. BASIDIA 4-spored. PLEUROCYSTIDIA 55-74 $\mu \mathrm{m}$ (av. $61 \mu \mathrm{m}$, SD $6 \mu \mathrm{m}) \times 12-21 \mu \mathrm{m}$ (av. $15 \mu \mathrm{m}$, SD $2 \mu \mathrm{m}) ; \mathrm{Q}=3.2-5.5$ (av. 4.2, SD 0.6) $(\mathrm{n}=$ 15), (sub)fusiform, (sub)utriform, also (sub)cylindrical, apex usually crystalliferous, with short pedicel, walls up to $1.5(2.0) \mu \mathrm{m}$ thick, pale yellowish with $3 \%$ KOH. CHEILOCYSTIDIA similar in appearance and size. PARACYSTIDIA not observed. CAULOCYSTIDIA in the upper part of the stipe, similar in form and size to hymenial cystidia, walls up to $1 \mu \mathrm{m}$ thick.

HOLOTYPE: Inocybe rufuloides Bon 1984, France, Somme, Cayeux-sur-Mer, Brighton-La Mollière, $P i$ nus, leg. M. Bon, J. Vast \& Claus, 18 May 1983 (LIPMB83038). SPORES 8.6-11.3 $\mu \mathrm{m}$ (av. $9.9 \mu \mathrm{m}$, SD 0.7 $\mu \mathrm{m}) \times 5.2-7.0 \mu \mathrm{m}($ av. $6.0 \mu \mathrm{m}$, SD $0.3 \mu \mathrm{m}) ; \mathrm{Q}=1.4-2.0$ (av. 1.7, SD 0.1) $(\mathrm{n}=40)$, smooth, with subacute to (sub)obtuse apex, with indistinct pseudopore. BASIDIA 4-spored. PLEUROCYSTIDIA 37-65 $\mu \mathrm{m}$ (av. $54 \mu \mathrm{m}$, SD $7 \mu \mathrm{m}) \times 9-17 \mu \mathrm{m}$ (av. $15 \mu \mathrm{m}$, SD $2 \mu \mathrm{m}$ ); Q $=3.0-4.2(\mathrm{av} .3 .7$, SD 0.3) $(\mathrm{n}=15)$, mostly (sub)fusiform or subutriform, sometimes with rather long and slightly undulate neck, with short pedicel, apex usually crystalliferous, walls up to 2.0 (3.0) $\mu \mathrm{m}$ thick, yellowish-greenish with $3 \% \mathrm{KOH}$. CHEILOCYSTIDIA similar in appearance and size. PARACYSTIDIA not observed. CAULOCYSTIDIA not studied (to preserve the material).

HOLOTYPE: Inocybe subpelargonium Beller 1982, France, Madirac, Créon, Gironde, frondose trees, 14 Oct. 1979 (LIP-7910142). SPORES 7.9-10.4 $\mu \mathrm{m}$ (av. $9.1 \mu \mathrm{m}$, SD $0.6 \mu \mathrm{m}) \times 4.5-6.0 \mu \mathrm{m}($ av. $5.1 \mu \mathrm{m}$, SD 0.3 $\mu \mathrm{m}) ; \mathrm{Q}=1.6-1.9$ (av. 1.8, SD 0.1) $(\mathrm{n}=40)$, smooth, (sub)amygdaloid, (sub)ellipsoid, apex (sub)obtuse), (sub)acute), sometimes subpapillate. BASIDIA 4-spored. PLEUROCYSTIDiA 45-63 $\mu \mathrm{m}$ (av. $53 \mu \mathrm{m}$, SD $6 \mu \mathrm{m}) \times 11-16 \mu \mathrm{m}$ (av. $14 \mu \mathrm{m}$, SD $2 \mu \mathrm{m}$ ); $\mathrm{Q}=$ 2.8-5.3 (av. 3.9, SD 0.7) ( $=15)$, (sub)fusiform, subutriform (sub)cylindrical, with rather short neck and short pedicel, apex usually crystalliferous, walls up to 2.0 (2.5) $\mu \mathrm{m}$ thick, yellowish-greenish with $3 \%$ KOH. CHEILOCYSTIDIA similar in appearance and size. PARACYSTIDIA not observed. CAULOCYSTIDIA not studied (to preserve the material).

ISOTYPE: Inocybe variispora Fern. Sas., 2002, Spain, Muskiz, province Biscay, 30T WN 8995, garden with Pseudotsuga menziesii (No 980504-01, Sociedad Micológica Gallarta-Gallarta Mikologia 


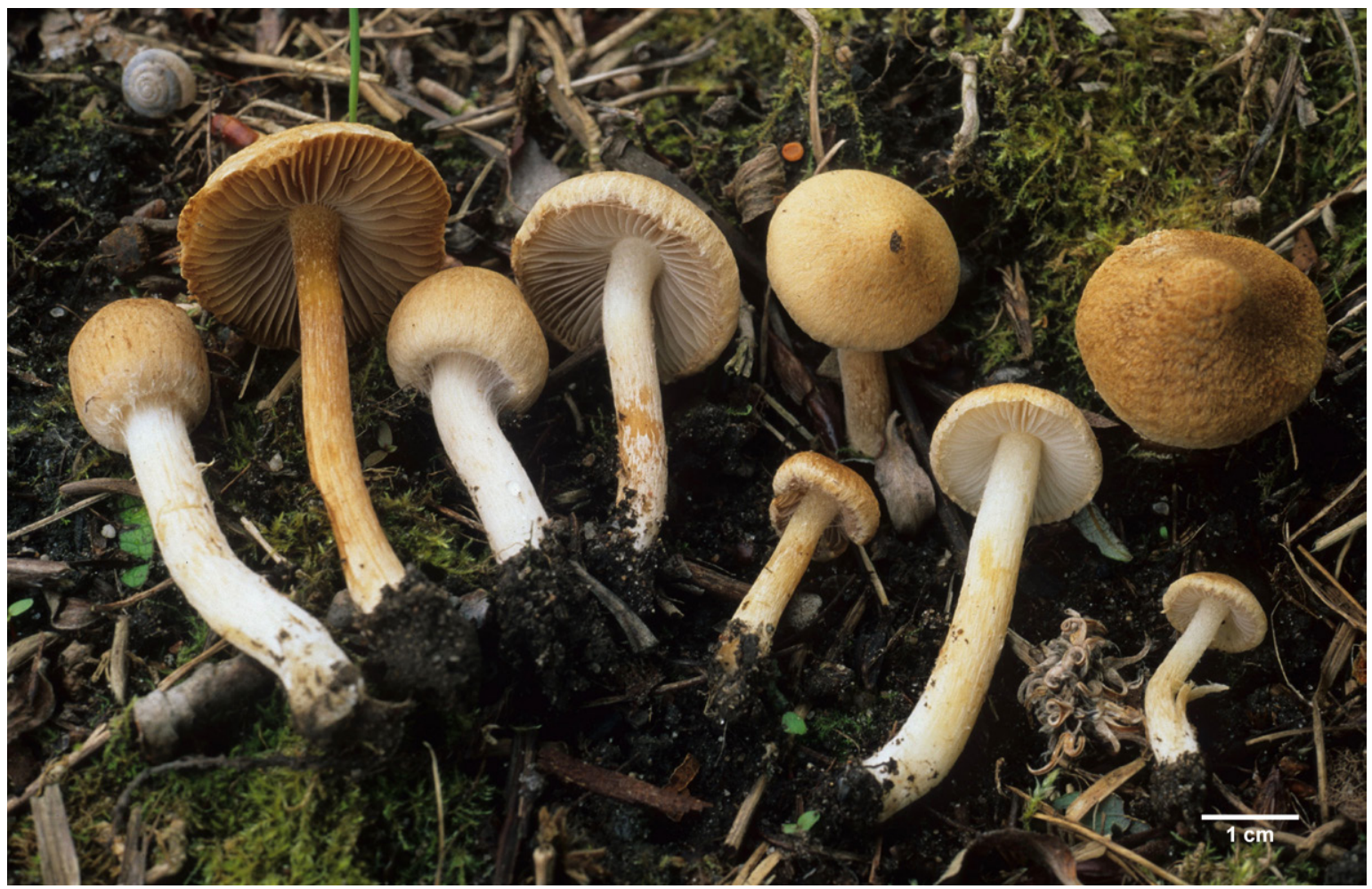

Fig. 5. Inocybe woglindeana, coll. Vauras 13558F; photograph J. Vauras.

Elkartea). SPORES 9.1-12.6 $\mu \mathrm{m}$ (av. $10.4 \mu \mathrm{m}$, SD 0.7 $\mu \mathrm{m}) \times 5.4-6.2 \mu \mathrm{m}$ (av. 5.7 $\mu \mathrm{m}$, SD $0.2 \mu \mathrm{m}$ ); $\mathrm{Q}=1.6-2.0$ (av. 1.8, SD 0.1) ( $\mathrm{n}=40)$, smooth, (sub)amygdaloid, apex (sub)acute, with faint pseudopore. BASIDIA 4-spored, seldom also 2-spored. PLEUROCYSTIDIA 45-70 $\mu \mathrm{m}$ (av. $54 \mu \mathrm{m}$, SD $8 \mu \mathrm{m}) \times 11-22 \mu \mathrm{m}$ (av. 15 $\mu \mathrm{m}, \mathrm{SD} 2 \mu \mathrm{m}) ; \mathrm{Q}=2.7-5.5$ (av. 3.7, SD 0.5) $(\mathrm{n}=15)$, mostly subfusiform to subutriform, without or with short neck, usually with short pedicel, apex usually very finely crystalliferous, walls up to $2.0(2.5) \mu \mathrm{m}$ thick, pale yellowish with $3 \% \mathrm{KOH}$. CHEILOCYSTIDIA similar in appearance and size. PARACYSTIDIA not observed. CAULOCYSTIDIA not present.

\section{Discussion}

The molecular support for Inocybe woglindeana as a species distinct from I. variispora is not strong and rests heavily on distance data from a single collection, albeit the type. The evidence includes a locus (V6) that has not been tested for the genus and for which we have data for no other species. We have analysed the available data in a multitude of ways and combinations: different sets of species and sequences; only ITS; with gap recoding [FastGap, vs. 1.2, Borchsenius 2009, Simmons \& Ochoterena 2000], Baysian Inference with MrBAYES 3.2.7a [Ronquist et al. 2012] on CIPRES [Miller et al. 2010]; ML with better fitting models, ultrafast bootstrap and SH-arl-tests in IQ-TREE [Guindon et al. 2010, Nguyen et al. 2015, Kalyaanamoorthy et al. 2017, Hoang et al. 2018]; analyses other than ML-based methods are less well suited to deal with missing data. However, the result was essentially the same generally concordant results and very little, if at all, support for the monophyly of I. woglindeana against I. variispora. Responsible for the lack of support for the split between I. variispora and I. woglindea$n a$, are presumably missing data and the fact that 


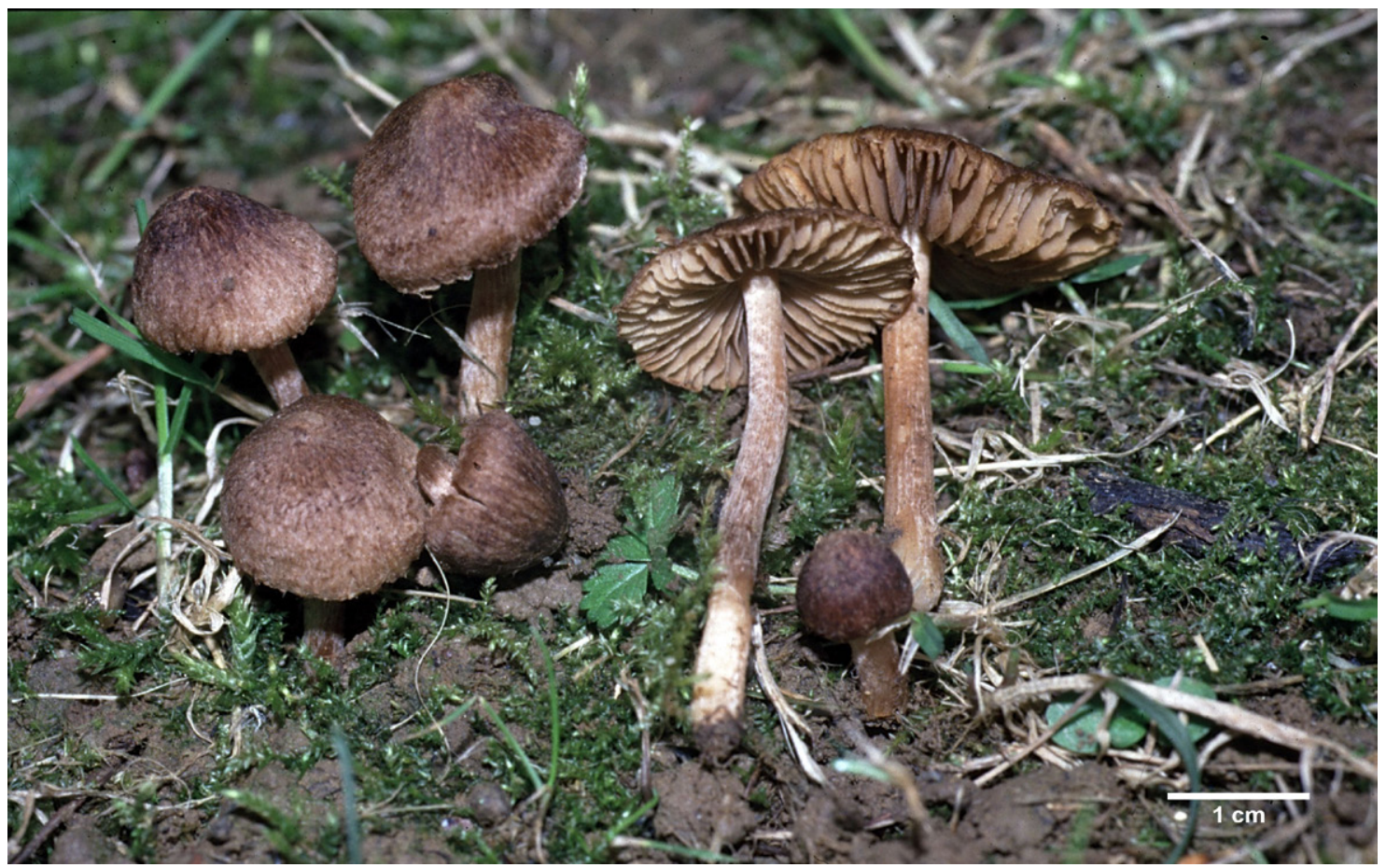

Fig. 6. Inocybe variispora, holotype, photograph R. Fernández Sasia.

only a single collection of this species is available. The bootstrap support for the I. woglindeana clade, below $75 \%$ in Fig. 1, increases to $98 \%$ when the sequence of the Thai collection DED8054a is removed from the analysis (details not shown). Although in terms of similarity one of the closest relatives of the I. woglindeana clade, homology assessment aka sequence alignment is not self-evident between DED8054a and the members of the I. woglindeana clade. Thus, the lack of support here could be an alignment issue. The collection DED8054a was a singleton in the study by Horak et al. (2015) and not further investigated.

Considering the molecular results in combination with morphological and ecological differences, we are confident that I. variispora and I. woglindeana are separate species. We expect that when sequence data for additional loci and collections or full genomes will become available, the support for this conclusion will increase.

Inocybe woglindeana has been found in exposed places: sandy and/or gravelly terrain with Salix and often Populus in Germany, Finland and Norway. Ectomycorrhiza or soil sample sequences suggest that the species occurs in Estonia (all samples are from places where Salix fragilis or Salix caprea were the only available ectomycorrhizal hosts, from an urban site as well as agricultural wasteland and a juniper woodland on limestone ;Tedersoo, unpubl.) and possibly also in the Tundra of Prudhoe Bay, Alaska, which is also known for calcareous habitats, presumably with Salix arctica or Dryas integrifolia (Timling et al. 2014). Whether this last sample is indeed a member of I. woglindeana cannot be determined based on the available information. There could well be a species complex around I. variispora as e.g. observed in Hebeloma (Cripps et al. 2019) or Lactarius (Barge et al. 2016), where temperate and arctic-alpine species are hard to separate molecularly and morphologically, and when representatives of different continents are considered, it becomes even harder to delimit species. However, even if this was the case, it would be an advantage to have a name, I. woglindeana, available for the set of collections 
distinguished by certain morphological features, habitat and molecular markers.

Inocybe woglindeana is characterised by often rather stout but usually rather small basidiomata, ochraceous to ochraceous brownish lanose pilei with ample whitish velipellis and cortina and conspicuously whitish lamellae when young, oblong smooth spores that can be ellipsoid or subcylindrical and have a length of more than $10 \mu \mathrm{m}$ on average. The hymenial cystidia are rather ventricose, mostly without neck and with a wide apex, quite thinwalled and often with truncate or roundish base. So far, in every collection elongate (sub)ellipsoid cystidia have been found (see microplate in Fig. 3, second cystidium from the left). It is worth noting, that spores and hymenial cystidia of the German collections are on average smaller than those of the Finnish collections, a phenomenon we already came across in another species, I. leochroma Bandini, Vauras \& B. Oertel (see Bandini et al. 2019), irrespective of examiner and microscope.

We are not aware of any other species that possesses all of the named characteristics, and there are only very few species that can possibly be confused with Inocybe woglindeana, owing to the colour of pileus, the habitat and the size of the spores etc. One of them, I. subpelargonium Beller, is according to Bon (1997) also fond of sandy terrain, as stated in Beller's original description (1982). It is subhygrophile, grows with frondose trees, and its smell reminds of Pelargonium leaves, being thus somehow sweetish-aromatic. However, the pileus of this species is according to the original description not lanose but fibrillose to subrimose, and the colour is ochraceous brownish, but darker near centre, resembling thus I. phaeodisca (Bon 1997) rather than I. woglindeana. No such colour contrast was observed in any of the collections of I. woglindeana - in this species, the umbo is not darker but paler in colour in older specimens. Furthermore, the examination of the holotype of I. subpelargonium confirmed that the microdetails are entirely different from those of I. woglindeana: The spores are much smaller, and the hymenial cystidia are shorter and narrower (Beller 1982, for details of the holotype see above and Fig. 7e). We do not have sequence data for this species available.

A species with rather long spores and sometimes growing on sandy ground is Inocybe involuta
Kuyper. It was originally found on the Dutch island of Terschelling by Eef Arnolds. However, as originally described and observed in many own collections (Kuyper 1989, Bandini et al. 2020), the colour of the pileus usually is reddish brown, and the stipe is often reddish. The hymenial cystidia are very different in shape compared to those of I. woglindeana, subfusiform and thick-walled (for details of holotype see above and Fig. 7b).

Inocybe inodora Velen., another species growing in sandy or gravelly, calcareous habitats, may look similar to I. woglindeana, and is also furnished with a pale velipellis, but the stipe is entirely pruinose, the spores are on average somewhat larger, the hymenial cystidia smaller and never almost "sac-shaped" or (sub)ellipsoid with apex and base looking almost or entirely alike (e.g. Kuyper 1986, Stangl 1989; for details of lectotype see above and Fig. 7a).

Inocybe pruinosa $\mathrm{R}$. Heim, another species that superficially may resemble $I$. woglindeana, is also found on sandy ground. However, the former often has a more yellowish pileus colour, the stipe is entirely pruinose, the spores are larger and the hymenial cystidia are clearly more thick-walled (Heim 1931, and e.g. Kuyper 1986, Stangl 1989).

Inocybe queletii Konrad, for which I. woglindeana was mistaken (see Table 1 and Kuyper 1986), is again similar in aspect, the pileus colour is yellowish, the surface rather smooth and the stipe is only pruinose at the apex (Konrad 1927, 1929, and e.g. Kuyper 1986, Stangl 1989). However, the basidiomes are larger, the spores are on average somewhat smaller, the hymenial cystidia are on average slimmer, with thicker walls and not with a roundish or truncate base. And the habitat is quite different: mountainous regions with Abies.

Inocybe neorufula Esteve-Rav., Macau \& Ferville is, like I. woglindeana, fond of sandy calcareous ground. It has a whitish velipellis and rather large spores, too, but the pileus is more foxy brown with a reddish tinge, and the hymenial cystidia do not have a roundish or truncate base (for details of isotype see above and Fig. 7c). Only Pinus, not Salix, is mentioned as potential mycorrhizal associate in the original description (Esteve-Raventós et al. 2012).

Inocybe exilis (Kuyper) Jacobsson \& E. Larss. was found in the neighbourhood of I. woglindeana both in Germany and in Finland. The pileus of this 


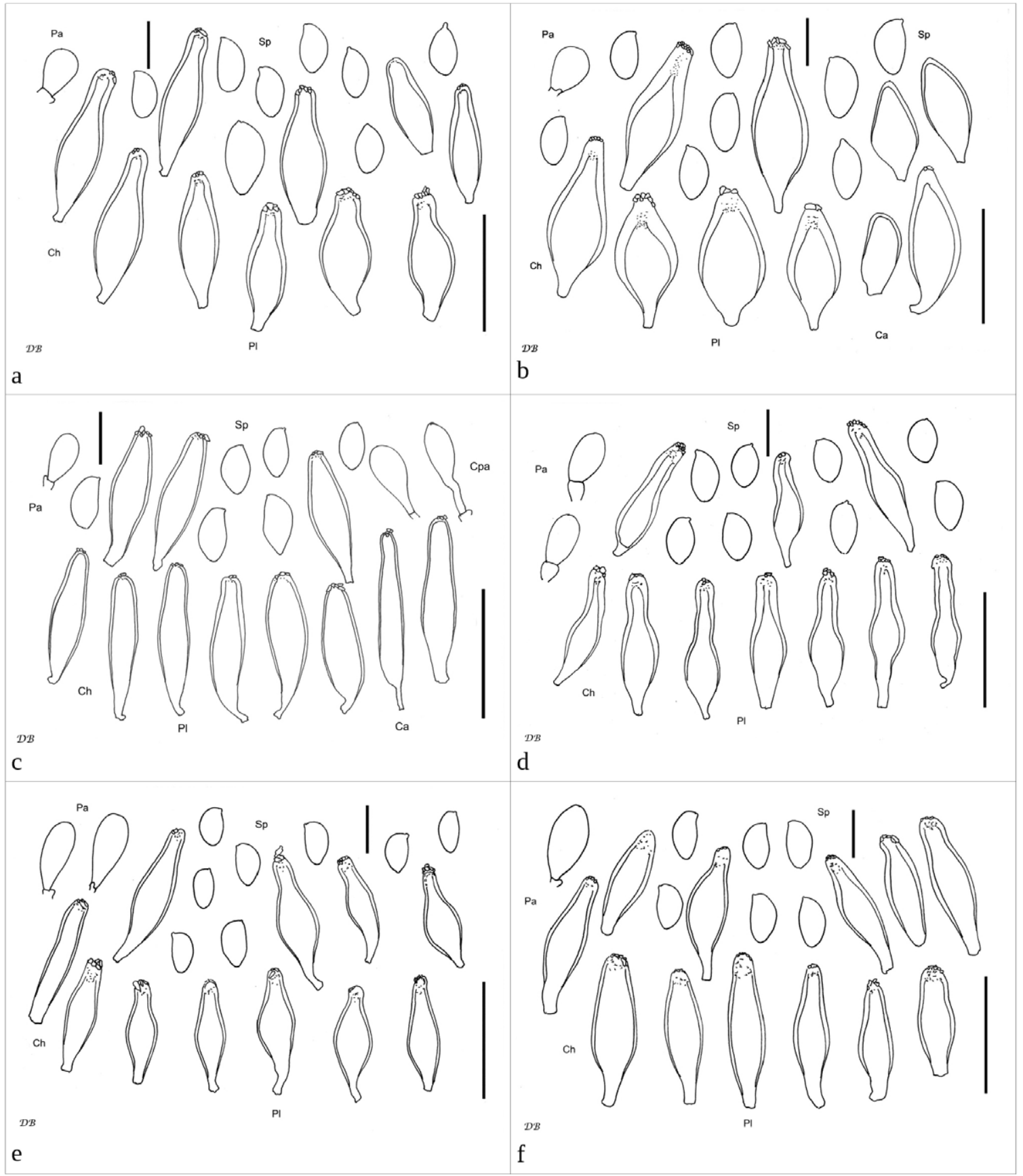

Fig. 7. Microscopic characters of type collections. a: Inocybe inodora (PR, bottle no. 156). b: I. involuta (L-0017086). c: I. neorufula (SMNS-STU-F-0901287). d: I. rufuloides (LIP-MB83038). e: I. subpelargonium (LIP-7910142).

f: I. variispora (No 980504-01). Ca = Caulocystidia, $\mathrm{Cpa}=$ Cauloparacystidia, $C h=$ Cheilocystidia, $\mathrm{Pa}=$ Paracystidia,

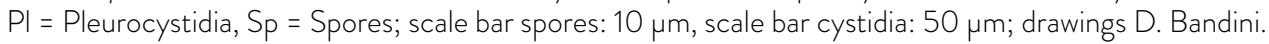


species is reddish brown in colour, the spores are on average larger, and the hymenial cystidia are usually more thick-walled and have no truncate or roundish base (Kuyper 1986). The same holds true for I. rufuloides Bon (Bon 1984, Kuyper 1986). For details of the holotype see above and Fig. $7 \mathrm{~d}$.

We also found I. nitidiuscula (Britzelm.) Lapl. in exposed sandy-gravelly locations with Salix nearby. Its pileus is normally somewhat reddish or at least with reddish tinges, but exceptionally it is also almost ochraceous. The species has rather long spores like I. woglindeana, but the hymenial cystidia are very different in shape, with rather narrow long necks, thicker walls and narrow apex.

The species that is most closely related genetically and in microscopical details to I. woglindeana is I. variispora. However, the hymenial cystidia of the latter are normally somewhat narrower, they are mostly pedicellate and the walls are generally somewhat thicker. And the elongate (sub)ellipsoidal shaped cystidia - typical for I. woglindeana - are missing. The macroscopical aspect, too, is quite different, since the pilei of $I$. variispora are dark brown - and not yellow-ochraceous (see Fig. 6). As Fernández Sasia (2002) highlights in his description, the general aspect of. I. variispora reminds strongly of a small I. lacera ("laspect général rappelle fortement un I. lacera de petite taille"), which cannot at all be said about the basidiomes of I. woglindeana. Also, the typical whitish velipellis, visible in young basidiomes of I. woglindeana, is missing in I. variispora, and the odour is described as spermatic ("spermatique évident"), while the odour of I. woglindeana is agreeable aromatic and never spermatic. The type of I. variispora was found next to Pseudotsuga menziesii in a garden (Fernández Sasia 2002), thus with a different host than I. woglindeana.

The number and size of the collections listed for I. woglindeana show that in the appropriate habitat, the species can often be found in large numbers. Such habitats are quite rare, at least in Central and Northern Europe, which probably is the reason why such a characteristic species has been overlooked in both Germany and adjacent areas as well as in the Nordic countries, or was misinterpreted as I. queletii or perhaps also as I. inodora.

\section{Acknowledgements}

We are grateful to the curators Javier Rejos (AH), Nicolien Sol (L) and Régis Courtecuisse (LIP) for the loan of specimens in their keeping, to Holger Thüs (STU) for handling the loans on our side, to Roberto Fernández Sasia (Muskiz, Biskay, Spain) for sending a part of an isotype of I. variispora and for the kind permission to print his photograph of the holotype of I. variispora and to Fernando Esteve-Raventós (Alcala, Spain) for his help regarding I. neorufula. Leho Tedersoo (University of Tartu) is thanked for sharing with us unpublished collection information of Estonian soil samples. We also thank FinBOL for support and are grateful that Bálint Dima (Eötvös Loránd University Budapest) allowed us to use two sequences of the FinBOL project. The contribution of $U$. Eberhardt was financed through the German Barcode of Life (GBOL) project, supported by the German Federal Ministry of Education and Research (BMBF FKZ 01LI1501I) as research for sustainable development (FONA; http://www.fona.de).

We finally thank Morten Pettersen (Fredrikstad, Norway) for his contribution to the study with valuable material and Ellen Larsson (Gothenburg, Sweden) for drawing our attention to I. variispora.

\section{References}

Altschul, S.F., Gish, W., Miller, W., Myers, E.W. \& Lipman, D.J. 1990: Basic local alignment search tool. Journal of Molecular Biology 215: 403-410.

Bandini, D., Oertel, B., Ploch, S., Ali, T., Vauras, J., Schneider, A., Scholler, M., Eberhardt, U. \& Thines, M. 2019: Revision of some central European species of Inocybe (Fr.: Fr.) Fr. subgenus Inocybe, with the description of five new species, Mycological Progress 18: 247-294. https://doi.org/10.1007/ s11557-018-1439-9).

Bandini, D., Oertel, B., Schüßler, C. \& Eberhardt, U. 2020: Noch mehr Risspilze: Fünfzehn neue und zwei wenig bekannte Arten von Inocybe, Untergattung Inocybe. Mycologia Bavarica 20: 13-101.

Barge, E.G., Cripps, C.L. \& Osmundson, T.W. 2016: Systematics of the ectomycorrhizal genus Lactarius in the Rocky Mountains alpine zone. Mycologia 108: 414-440.

Beller, J. 1982: Novitates - Espèces nouvelles. Documents Mycologiques 12(46): 32. 
Bizio, E., Ferisin, G. \& Dovana, F. 2017: Note sul di variabilità di Inocybe griseotarda. Rivista di Micologia 60: 59-70.

Borchsenius, F. 2009: FastGap 1.2. Department of Biosciences, Aarhus University, Denmark. Published online at http://www. aubot.dk/FastGap_home.htm.

Bon, M. 1984. Macromycètes de la zone maritime picarde (8ème supplément). Les inocybes sabulicoles. Documents Mycologiques 14: 9-40.

Bon, M. 1997: Clé monographique du genre Inocybe (Fr.) Fr. (2ème partie). Documents Mycologiques 27: 1-77.

Bon, M. 1998: Clé monographique du genre Inocybe (Fr.) Fr. (3ème partie). Documents Mycologiques 28: 1-45.

Bougher, N.L. \& Matheny, P.B. 2011: Two species of Inocybe (fungi) introduced into Western Australia. Nuytsia 21: 139-148.

Cailleux, A. 1981: Code des couleurs des sols, Boubée, Paris.

Cripps, C., Eberhardt, U., Schütz, N., Beker, H.J., Evenson, V.S. \& Horak, E. 2019: The genus Hebeloma in the Rocky Mountain alpine zone. MycoKeys 46: 1-54.

Esteve-Raventós, F., Macau N. \& Ferville, A. 2012 [2011]: Inocybe neorufula sp. nov., un nouveau nom pour I. rufula au sens de Malençon. Bulletin de la Société Mycologique de France 127: 189-200.

Fernández Sasia, R. 2002: Sur une nouvelle espèce du genre Inocybe (Fr. : Fr.) Fr. identifiée au Pays Basque espagnol: Inocybe variispora. Documents Mycologiques 231: 25-31.

Gardes, M. \& Bruns, T.D. 1993: ITS primers with enhanced specificity for basidiomycetes - application to the identification of mycorrhizae and rusts. Molecular Ecology 2: 113-118.

Gonzalez, P. \& Labarère, J. 1998: Sequence and secondary structure of the mitochondrial small-subunit rRNA V4, V6, and $V 9$ domains reveal highly species-specific variations within the genus Agrocybe. Applied Environmental Microbiology 64: 4149-4160.

Guindon, S., Dufayard, J.-F., Lefort, V., Anisimova, M., Hordijk, W. \& Gascuel, O. 2010: New algorithms and methods to estimate Maximum-Likelihood phylogenies: Assessing the performance of PhyML 3.0. Systematic Biology 59: 307-321.

Heim, R. 1931. Le genre Inocybe, Encyclopédie Mycologique, vol 1, 2nd edn. Lechevalier, Paris.

Hoang, D.T., Chernomor, O., von Haeseler, A., Minh, B.Q. \& Vinh, L.S. 2018: UFBoot2: Improving the ultrafast bootstrap approximation. Molecular Biology and Evolution 35: 518-522.
Holmgren, P.K., Holmgren, N.H. \& Barnett, L.C. 1990 Index Herbariorum, 8th edn. Botanic Garden, New York.

Horak, E., Matheny, B., Desjardin, D.E. \& Soytong, K. 2015: The genus Inocybe (Inocybaceae, Agaricales, Basidiomycota) in Thailand and Malaysia. Phytotaxa 230: 201-238.

Kalyaanamoorthy, S., Minh, B.Q., Wong, T.K.F., von Haeseler, A. \& Jermiin, L.S. 2017: ModelFinder. Nature Methods 14: 587-589.

Katoh, K., Kuma, K., Toh, H. \& Miyata, T. 2005: MAFFT version 5: improvement in accuracy of multiple sequence alignment. Nucleic Acids Research 33: 511-518.

Katoh, K., Rozewicki, J. \& Yamada, K.D. 2019. MAFFT online service: multiple sequence alignment, interactive sequence choice and visualization. Briefings in Bioinformatics 20: 1160-1166.

Konrad, P.A. 1927: Notes critiques sur quelques Champignons du Jura, 3ème série. Bulletin de la Société Mycologique de France 43: 145-204.

Konrad, P.A. 1929: Notes critiques sur quelques Champignons du Jura, 4. Bulletin de la Société Mycologique de France 45: 35-77.

Kropp, B.R., Matheny, P.B. \& Hutchison, L.J. 2013: Inocybe section Rimosae in Utah: phylogenetic affinities and new species. Mycologia 105: 728-747.

Kropp, B.R., Matheny, P.B. \& Nanagyulyan, S.G. 2010: Phylogenetic taxonomy of the Inocybe splendens group and evolution of supersection 'Marginatae'. Mycologia 102: 560-573.

Küppers, H. 1981: DuMonts Farben-Atlas, 2nd ed, Köln.

Kuyper, T.W. 1986: A revision of the genus Inocybe in Europe. I. Subgenus Inosperma and the smooth-spored species of subgenus Inocybe. Persoonia Suppl 3:1-247.

Kuyper, T.W. 1989 Studien in Inocybe IV. Zeitschrift für Mykologie 55: 111-114.

Larsson, A. 2014: AliView: a fast and lightweight alignment viewer and editor for large data sets. Bioinformatics 30: 3276-3278.

Latha, K.P.D., Manimohan, P. \& Matheny, P.B. 2016: A new species of Inocybe representing the Nothocybe lineage. Phytotaxa 267: 40-50.

LoBuglio, K.F., Rogers, S.O. \& Wang, C.J.K. 1991: Variation in ribosomal DNA among isolates of the mycorrhizal fungus Cenococcum geophilum. Canadian Journal of Botany 69: 2331-2343. 
Marchetti, M., Franchi, P. \& Consiglio, G. 2014: Tipificazione di alcune Inocybe di Britzlmayr. Rivista di Micologia 57: 127-178.

Matheny, P.B., Aime, M.C., Bougher, N.L., Buyck, B., Desjardin, D.E., Horak, E., Kropp, B.R., Lodge, D.J., Soytong, K., Trappe, J.M. \& Hibbett, D.S. 2009: Out of the Palaeotropics? Historical biogeography and diversification of the cosmopolitan ectomycorrhizal mushroom family Inocybaceae. Journal of Biogeography 36: 577-592.

Matheny, P.B., Hobbs, A.M. \& Esteve-Raventós, F. 2019: Genera of Inocybaceae: New skin for the old ceremony. Mycologia 112: 83-120.

Matheny, P.B. \& Kudzma, L.V. 2019: New species of Inocybe (Inocybaceae) from eastern North America 1. The Journal of the Torrey Botanical Society 146: 213-235.

Matheny, P.B., Liu, Y.J., Ammirati, J.F. \& Hall, B.D. 2002: Using RPB1 sequences to improve phylogenetic inference among mushrooms (Inocybe, Agaricales). American Journal of Botany 89: 688-698.

Miller, M.A., Pfeiffer, W. \& Schwartz, T. 2010: Creating the CIPRES science gateway for inference of large phylogenetic trees. In: Xavier, J. ed.: Gateway Computing Environments Workshop (GCE) Proceedings of a meeting held 14 Nov 2010, New Orleans, Louisiana, USA. 1-8. Institute of Electrical and Electronics Engineers (IEEE), Piscataway, New Jersey.

Mühlmann, O. \& Peintner, U. 2008: Mycobionts of Salix herbacea on a glacier forefront in the Austrian Alps. Mycorrhiza 18: 171-180.

Munsell, O. 2009: Soil colour charts. X-Rite. Grand Rapids MI.

Nguyen, L.-T., Schmidt, H.A., von Haeseler, A. \& Minh, B.Q. 2015: IQ-TREE: A fast and effective stochastic algorithm for estimating maximuml ikelihood phylogenies. Molecular Biology and Evolution 32: 268-274.

Oberkofler, I. \& Peintner, U. 2008: Detection of soil fungal communities in an alpine primary successional habitat: does pooling of DNA extracts affect investigations? Annals of Microbiology 58: 585-595.

Peintner, U., Bougher, N.L., Castellano, M.A., Moncalvo, J.M., Moser, M.M., Trappe, J.M. \& Vilgalys, R. 2001: Multiple origins of sequestrate fungi related to Cortinarius (Cortinariaceae). American Journal of Botany 88: 2168-2179.

Rambaut, A. 2006-2018: aTree. Tree figure drawing tool. Institute of Evolutionary Biology, University of Edinburgh, Edinburgh.
Ronquist, F., Teslenko, M., Van der Mark, P., Ayres, D.L., Darling, A., Höhna, S., Larget, B., Liu, L., Sucharard, M.A. \& Huelsenbeck, J.P. 2012: MrBayes 3.2: Efficient Bayesian phylogenetic inference and model choice across a large model space. Systematic Biology 61: 539-542.

Ryberg, M., Larsson, E. \& Jacobsson, S. 2010: An evolutionary perspective on morphological and ecological characters in the mushroom family Inocybaceae (Agaricomycotina, Fungi). Molecular Phylogenetics and Evolution 55: 431-442.

Ryberg, M., Nilsson, R.H., Kristiansson, E., Töpel, M., Jacobsson, S. \& Larsson, E. 2008: Mining metadata from unidentified ITS sequences in GenBank: a case study in Inocybe (Basidiomycota). BMC Evolutionary Biology 8: 50. https://doi.org/10.1186/1471-2148-8-50.

Simmons, M.P. \& Ochoterena, H. 2000: Gaps as characters in sequence-based phylogenetic analyses. Systematic Biology 49: 369-381.

Stamatakis, A. 2014: RAxML Version 8: a tool for phylogenetic analysis and post-analysis of large phylogenies. Bioinformatics 30: 1312-1313.

Stangl, J. 1989: Die Gattung Inocybe in Bayern. Hoppea 46: 5-388.

Swofford, D.L. 2002: PAUP*. Phylogenetic Analysis Using Parsimony (and other methods). 4.0 ed. Sinauer Associates, Sunderland, Massachusetts.

Timling, I., Walker, D.A., Nusbaum, C., Lennon, N.J. \& Taylor, D.L. 2014: Rich and cold: diversity, distribution and drivers of fungal communities in patterned-ground ecosystems of the North American Arctic. Molecular Ecology 23: 3258-3272.

Vellinga, E.C. 1988: Glossary. In: Bas, C., Kuyper, T.W., Noordeloos, M.E., Vellinga, E.C. (eds.) Flora Agaricina Neerlandica, vol 1. Balkema, Rotterdam \& Brookfield, pp 54-64.

Vilgalys, R. \& Hester, M. 1990: Rapid genetic identification and mapping of enzymatically amplified ribosomal DNA from several Cryptococcus species. Journal of Bacteriology 172: 4238-4246.

White, T.J., Bruns, T., Lee, S. \& Taylor, J. 1990: Amplification and direct sequencing of fungal ribosomal RNA genes for phylogenetics. In: Michael, A.J., Gelfand, D.H., Sninsky, J.J. \& White, T.J. (eds). PCR protocols: a guide to the methods and applications, 315-322. Academic Press, New York. 